\title{
PHOTOISOMERIZATION PROCESSES OF AZOBENZENE COMPOUNDS IN THIN POYMER FILMS
}

\author{
B. Niparte ${ }^{1}$, I. Muzikante ${ }^{1}$, E. Fonavs ${ }^{1}$, D. Gustina ${ }^{2}$ \\ ${ }^{1}$ Institute of Solid State Physics, University of Latvia, \\ LV 1063 Riga, Latvia \\ ${ }^{2}$ Latvian Institute of Organic Synthesis \\ e-mail: baiba.niparte@gmail.com
}

\begin{abstract}
One of the most important properties of the molecular switches is turning of a molecule by external action, e.g. by irradiation with light of definite wavelength. The molecules of promise for the molecular switches are those with azobenzene moiety. When azobenzene is irradiated with light of definite wavelength, it is possible to observe the process of trans/cis isomerisation. In this work, the influence of photoisomerisation processes on the changes in the surface potential of a novel azobenzene compound is investigated.

We have studied the surface potential of a PMMA polymer film with polar azobenzene derivative of different concentrations. To orient azobenzene molecules in the film the corona poling method was used, and for studying the surface potential variations - the Kelvin probe method. The photoreaction time constant of the fast response (several seconds) was found to be almost independent of the molecular concentration in the polymer film and of the absorbed light intensity in the bulk of a sample. In contrast, the amplitude of photoinduced changes in the surface potential depends both on the concentration of azobenzene molecules and on the absorbed light intensity in bulk of the host-guest polymer film.
\end{abstract}

Key words: azobenzene compounds, surface potential, host-guest polymer film, photoinduced switching processes.

\section{INTRODUCTION}

Switching properties of organic materials are of considerable promise owing to their potential applications in electronic and information storage devices. A simple, quick and effective stimulus to induce such a switching in information storage systems is external light [1]. Azobenzene derivatives were chosen, which are polar because of their electron donor and electron acceptor parts. When these parts are shifting with respect to each other, the electric dipole of such a molecule changes [2].

To observe the switching processes of the molecules it is important that they are in two stable molecular states and that the switching process is reversible. In each of the states these molecules have different properties owing to the changes of their dipole moment, structure, etc. [3].

For azobenzene molecules two models of the isomerization process exist, which is described by the molecular rotation or inversion. To have two photostationary states of isomerization it is necessary to irradiate the molecules by the 
light of appropriate wavelength for the two states. When the photostationary state is settled, it is possible to calculate the time constants of the processes [4].

\section{MOLECULES UNDER CONSIDERATION}

The experiments were done with azobenzene derivative 6-[4-(4-dicyclohexylsulfomyl-phenylazo)-phenoxy]-hexanoic acid (A-45) (Fig. 1) synthesized at the Latvian Institute of Organic Synthesis. The azobenzene derivative possesses a high value of molecular dipole moment also in trans-isomer, which is determined by polar groups in the molecule. According to the RHF ab initio calculations with basis set $6-31 \mathrm{G}^{* *}$ by Gaussian G09W software package, the dipole moment of trans-isomer is $5.11 \mathrm{D}$, and that of cis-isomer - 7.14 D. One of the main properties of an azobenzene derivative is that the molecule can change its geometry and dipole moment when irradiated with wavelengths corresponding to the two states: trans- and cis-isomers [4].

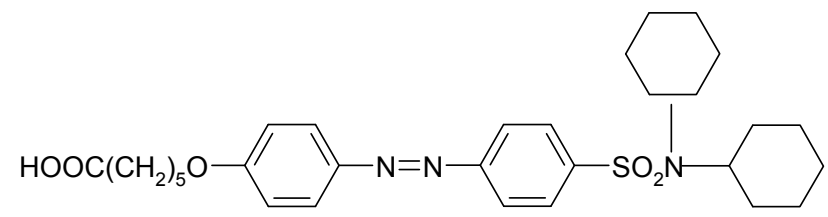

Fig. 1. Azobenzene derivative A-45.

\section{SURFACE POTENTIAL}

To study the electrical properties of polar molecules a method based on measuring the surface potential of a polymer film was used. The method provides useful information on the structural and electronic properties of the oriented films [5]. The surface potential is the difference of the potentials between the organic film and the gaseous phase upon this film. The electrical polarization associated with a layer of molecular dipoles gives rise to the potential difference across the sample [6]. The surface potential of a polymer film depends on the packing density and orientation of the polar molecules. When such a molecule is irradiated, changes in the molecular dipole moment normal to the surface of the film occur, which makes it possible to observe the changes of surface potential $U_{S}$. This potential is related to the dipole moment normal to the plane of substrate $\mu_{x}$ according to the equality:

$$
\mu_{x}=\varepsilon \varepsilon_{0} S U_{S}
$$

where $S$ is the average area occupied by the molecules on the substrate surface;

$\varepsilon, \varepsilon_{o}$ is the dielectric permittivity of the molecules and of vacuum, respectively.

\section{EXPERIMENTAL}

\subsection{Preparation of thin polymer films}

Thin polymer films were made as a host-guest system's layers consisting of syndiotactic polymethylmetacrylate s-PMMA (host), which act as a polymer 
matrix, and of azobenzene type molecules A-45 (guest). To dissolve these two components chloroform was used. To prepare the samples, the spin-coating method was applied. To make a lower electrode, the polymer film was spread on a glass substrate covered with an indium-tin oxide (ITO) layer.

We prepared 7 samples of differing molecular concentration: 1, 3, 5, 10, 15, 20 and $25 \mathrm{wt} \%$, and 10 samples of varying thickness at the optimal molecular concentration of $3 \mathrm{wt} \%$. After preparation, the samples were left for at least 7 days in the air to achieve full evaporation of chloroform.

The thickness of polymer films was measured using a surface profiler Veeco Dektak 150. For the samples with different molecular concentration the thickness values were in the range $1.0-1.6 \mu \mathrm{m}$. At the optimal concentration of $3 \mathrm{wt} \%$, the thicknesses of ten samples were $0.03-1.30 \mu \mathrm{m}$.

\subsection{Orientation of thin polymer films}

When thin polymer films are obtained the molecules are arranged randomly in the sample, and the total dipole moment is tending to zero. For further electric experiments it is necessary to orient the molecules in one direction in order to obtain the maximum dipole moment. For this purpose the corona poling method was used [7, 8]. In the process of orientation, the samples were heated at the temperature $100{ }^{\circ} \mathrm{C}$ (close to the glass transition temperature of s-PMMA $[8,9]$ ) to achieve that the polymer matrix becomes elastic and the polar molecules can orient in the direction of the electric field.

To orient the samples in a definite region, a mask with the diameter of $1 \mathrm{~cm}$ was used. The upper electrode was a tungsten wire with the diameter of $23.5 \mu \mathrm{m}$. The procedure of orientation lasted 10 min with the corona current being $0.5 \mu \mathrm{A}$ and the voltage $2.7-6.4 \mathrm{kV}$ applied to a tungsten wire. After $10 \mathrm{~min}$ of orientation, with the electric field kept constant, the sample was cooled down to $30^{\circ} \mathrm{C}$. Further experiments were carried out after 7 days to achieve the relaxation of the electrets. The dipole electrets for photonic applications contain chromophore dipoles, which consist of acceptor and donor groups linked by a bridge of a delocalized $\pi$-electron system. During the time of relaxation a decrease in the surface potential was observed $[7,9]$.

To investigate the structure of the oriented samples the optical microscope Nikon Eclipse L150 was used.

\subsection{Measurements of surface potential}

The Kelvin probe (KP) method was applied to investigate the surface potential of the film [6] (Fig. 2a).

The method was chosen due to its being non-destructive and, therefore, the possibility to run experiments many times with the same sample. In the experiments a home-made device was used [6] (see Fig. 2b). The samples were irradiated through the ITO electrode with two different wavelengths using a pallet with two light emitting diodes (LEDs), with a 5 min switchover time. The wavelengths of the diodes were chosen close to the trans- and cis-isomer absorption maxima, i.e. $365 \mathrm{~nm}\left(I_{o}=1.4 \mathrm{~mW}\right)$ and $460 \mathrm{~nm}\left(I_{o}=1.3 \mathrm{~mW}\right)$. The experiments were done at the room temperature in air. The time constant for the device was $\sim 2$ $3 \mathrm{~s}$. 

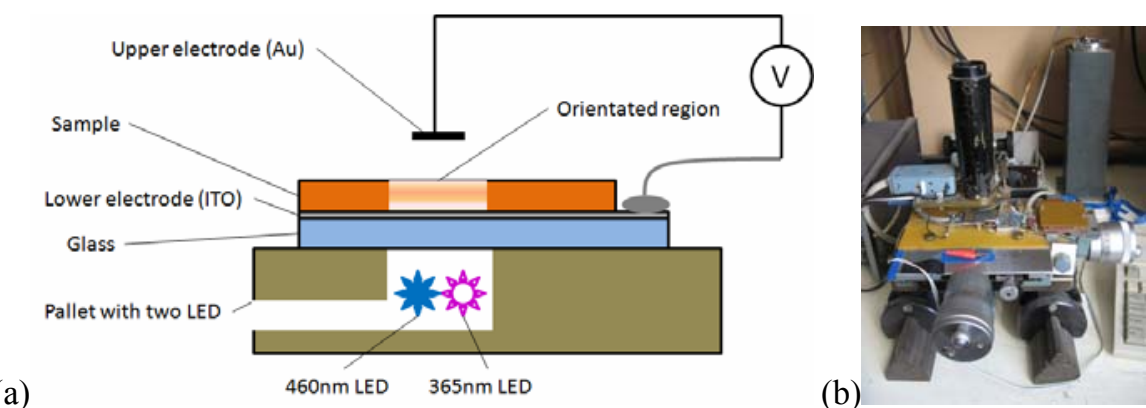

Fig. 2. Scheme of Kelvin's probe (a) and of the home-made device (b).

\section{RESULTS AND DISCUSSION}

From the images made with the optical microscope it follows that after orientation the molecules have a tendency to form different aggregates/crystallites in the polymer matrix. The process of aggregation happens mostly at the corona poling, when the sample is heated at glass transition temperature $T_{g}$ of the polymer, because the polymer matrix becomes flexible and the polar molecules can easily turn and/or move in the direction of the electric field. At the same time, they may combine making aggregates, and in this case the dipole moment is zero or close to it. The dipole moment of the polymer film depends on the number of free molecules; however, due to the formation of crystallites the number of free molecules decreases [10]. In the images it is also seen that the number of aggregates increases with the molecular concentration. At the same time, for the samples of different thickness no changes in the concentration of aggregates were observed.

In further experiments that were done 7 days after orientation, the samples with different molecular concentration were used. In the regions where the corona poling was done the photoinduced changes in the surface potential occurred. For all the samples the reversible process of surface potential $U_{S}$ was observed (Fig. $3 a$ ). The surface potential $U_{S}$ increased under irradiation at $365 \mathrm{~nm}$ - the wavelength corresponding to the trans-to-cis isomerization. The surface potential returns to the initial value when the sample is irradiated with $460 \mathrm{~nm}$ light, which corresponds to the cis-to-trans isomerization.

The main difference noticed is that for the samples with a high molecular concentration (from 10 to $25 \mathrm{wt} \%$ ) this process becomes reverse (Fig. $3 b$ ). As of now, it is difficult to explain these effects, so further experiments are needed. When the experiments were repeated 8 days later (i.e. 15 days after the orientation) only the samples with a low concentration $(1,3$ and $5 \mathrm{wt} \%)$ were used, with the same result obtained.

The photoinduced surface potential $U_{S}$ depends on the irradiation time $t$. This dependence can well be approximated by two exponential functions [11]:

$$
U_{S}(t)=A e^{\frac{t}{\tau_{A}}}+B e^{\frac{t}{\tau_{B}}}
$$

where $A, B$ are the amplitudes;

$\tau_{A}, \tau_{B}$ are the photoreaction time constants that characterize the response of surface potential changes to the irradiation. 
The function in Eq.(2) consists of two exponents that describe at least two different processes in a polymer film during irradiation. After several repeated cycles the amplitude and the photoreaction time did not change. As is also seen in Fig. 3, the initial fastest response $\tau_{A}, \tau_{B}$ was in the order of several seconds, while the slower response $\tau_{B}$ was in the order of several minutes.

(a)
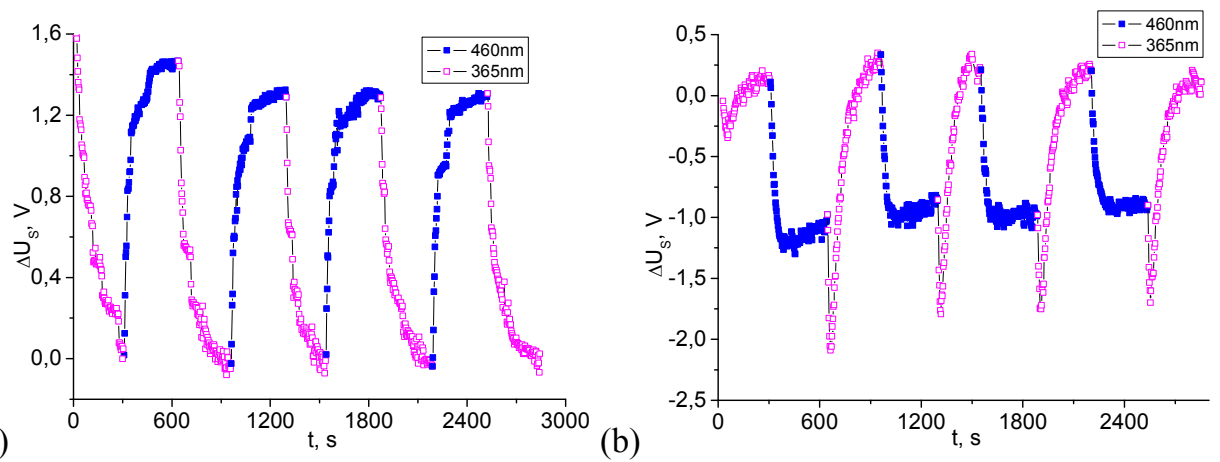

Fig. 3. Changes in the surface potential of samples with A-45 1wt $\%(a)$ and A-45 25wt $\%(b)$ under irradiation with light at $460 \mathrm{~nm}$ and $365 \mathrm{~nm}$ alternately.

In the literature (e.g. [11]) about the decay of nonlinear optical properties, the initial fastest response is attributed to the processes of a molecule's turning (by rotation or/and inversion) into another position, while the slower response - to the process of reorganisation of molecular order (thermal relaxation of the host-guest systems). This reorganisation is caused by the interaction between polar molecules in the polymer matrix and by that between the polar molecules and the polar groups of the polymer. The second process in all measurements for all the samples was too long and never became saturated, therefore only the fastest component was studied for further applications.

As is seen in Fig. $4 a, b$, the amplitude $A$ increases with the molecular concentration, while the photoreaction time $\tau_{A}$ practically does not change.

(a)
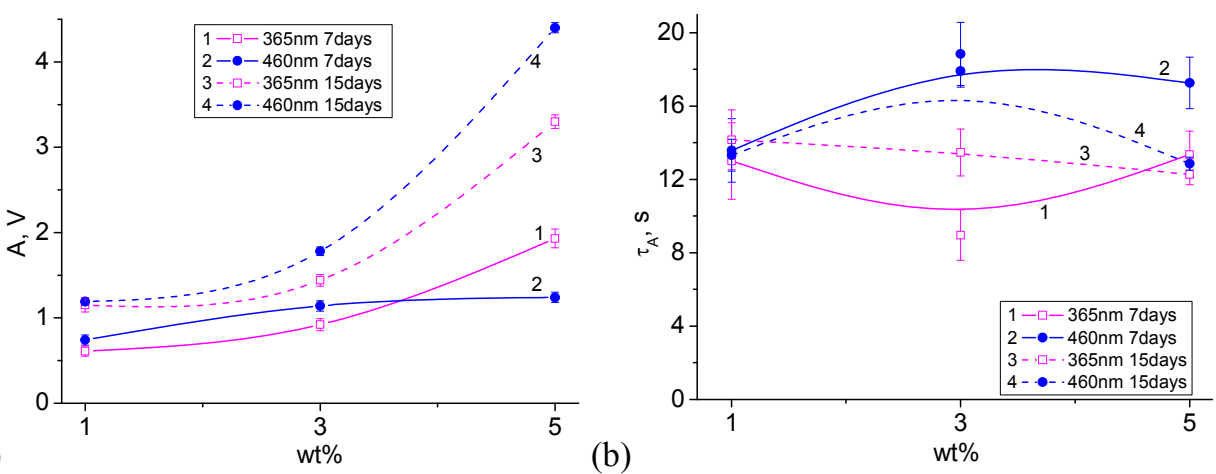

Fig. 4. Changes in amplitude $A$ of surface potential (a), and photoreaction time constant $\tau_{A}(b) v s$. the molecular concentration 7 and 15 days after the corona poling.

After orientation, an accumulated charge was created on the surface of the sample. The host-guest films of azobenzene derivatives may therefore to be attri- 
buted to the oriented-dipole electrets which contain oriented molecules with permanent dipole moments.

Due to that, a quasi-permanent internal electric field is created. This excessive electric field influences the value of the surface potential. During the measurements it was observed that the permanent surface potential increases from $40 \mathrm{~V}$ to $100 \mathrm{~V}$ for the molecular concentration of $1-10 \mathrm{wt} \%$. For the molecular concentration of 10-25 wt \% this potential decreases from $100 \mathrm{~V}$ to $60 \mathrm{~V}$.

Similar measurements were taken for the samples of varying thickness. Using the charts obtained with the KP method it is possible to determine the thickness limit for the samples. The measurement results for the surface potential show a smaller noise ratio for the samples with the thickness of $0.5-1.3 \mu \mathrm{m}$, whereas for $0.03-0.5 \mu \mathrm{m}$ thick samples the results are more irregular and show higher level of noise. These irregularities may be explained by too small thickness and too low surface potential of the samples.

Due to the structure of the experimental setup, the samples were irradiated through the bottom electrode. Up to now it has been assumed that for the surface measurements the KP method was applied. As the samples were of varying thickness, it was necessary to calculate the intensity of light $I_{S}$ that reached the surface of the sample (Fig. $5 a$ ):

$$
I_{S}=I_{o} e^{-\alpha L},
$$

where $I_{o} \quad$ is the light intensity of the LED;

$\alpha=D / L_{o}$ is the absorption coefficient of the A- $45+$ s-PMMA film, a.u. $/ \mu \mathrm{m}$;

$L \quad$ is the thickness of the sample.

As a result of calculation, we obtained an unexpected decrease in amplitude A of the surface potential with increasing light intensity. We may assume that the photoinduced changes of the surface potential are affected not only by the processes on the surface. Next, we took into account the intensity of light that was absorbed in the film (Fig. 5a):

$$
I_{A}=I_{o}\left(1-e^{-\alpha L}\right) .
$$

(a)

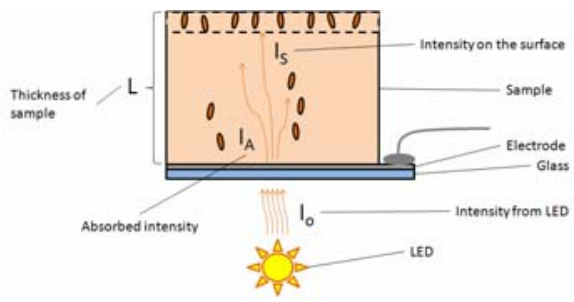

(b)

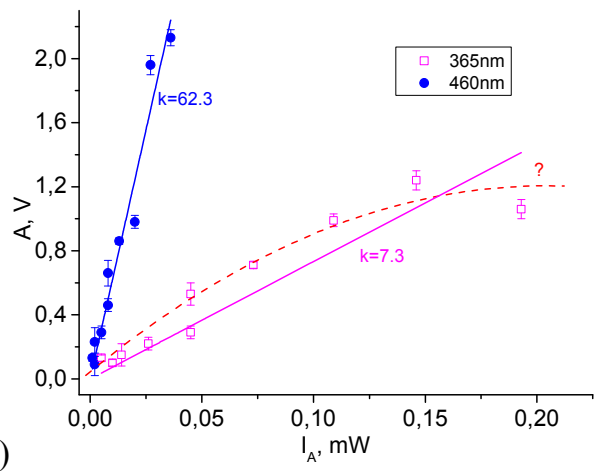

Fig. 5. Scheme of irradiation of the sample (a); amplitude of the surface potential vs. the light intensity absorbed in the polymer film with $3 \mathrm{wt} \%$ A-45 azobenzene molecules and thickness 1.29 $\mu \mathrm{m}(b)$. 
As shown in Fig. $5 b$, for further calculations it is important to consider also the processes going in the bulk of a sample. At lower intensities a linear dependence of surface potential amplitude variations is observed, whereas at higher light intensities there is a tendency towards saturation. Due to different values of the absorption coefficients at $365 \mathrm{~nm}$ and $460 \mathrm{~nm}$, higher absorbance intensities were reached only at $365 \mathrm{~nm}$.

The following step was to verify if these processes are the same when the LED light intensity is varying. For these experiments three different filters for decreasing the intensity $(1.6,2.5$ and 4 times) were used. The thickness of the sample was $L=1.29 \mu \mathrm{m}$. Again, a linear dependence of the surface potential amplitude on the absorbed light intensity $\left(I_{A}\right)$ was observed. It could be assumed that the photoinduced changes in the surface potential are caused by the one-photon absorption, and the processes are also going in the bulk of the sample.

\section{CONCLUSIONS}

The photoinduced switching of the surface potential caused by the molecular photoisomerisation of the polymer films with azobenzene derivative A-45 molecules incorporated in a polymer s-PMMA matrix has been observed when the samples were irradiated with $365 \mathrm{~nm}$ and $460 \mathrm{~nm}$ light. These processes are well distinguished for comparatively thick samples $(>0.5 \mu \mathrm{m})$ and low molecular concentration (1-5 wt\%).

The photoreaction time constant of the fast response (several seconds) is almost independent of the molecular concentration in polymer films and the intensity of light absorbed in the bulk of the sample.

The amplitude of the photoinduced variations in the surface potential increases both with the molecular concentration in the sample and the intensity of light absorbed in the bulk of the polymer film. At higher light intensities the value of this amplitude is saturated.

From our experiments follows the importance of taking into account that the processes on the polymer film surface are influenced by those going in its bulk when the samples are irradiated from the bottom.

\section{ACKNOWLEDGEMENTS}

The authors thank Dr. E. Markava for the help in synthesising the azobenzene derivative and E. Laizane for fabrication of the host-guest samples. The authors are grateful to M. Rutkis for dipole moment calculations.

This work is supported by National Research Program in Material Sciences of Latvia (2005-2009).

\section{REFERENCES}

1. Physics of Organic Semiconductors (2005). Eds. W. Brütting. Weinheim: Wiley-VCH, p. 536.

2. Neilands, O. (1977). Organic Chemistry. Riga: Zvaigzne ABC (in Latvian)

3. Muzikante, I., Markava, E., Gustina, D., Gerca, L., Rutkis, M., Fonavs, E., Stiller, B., \& Brehmer, L. (2001). Reversible optical storage utilizing photoinduced reorientation of azobenzene derivatives in organized films. Ferroelectrics, 258, 101-112.

4. Rau, H. (2002). Photoisomerization of azobenzenes. In: Photoreactive organic thin films. Academic Press, pp. 3-104. 
5. Muzikante, I., Fonavs, E., Stiller, B., Brehmer, L. (2005). Photoinduced phenomena in organised polar organic films. Advances in Colloid and Interface Science, 116, 133141.

6. Vilitis, O., Fonavs, E., \& Muzikante, I. (2001). A system for measuring surface potential by the Kelvin-Zisman vibrating capacitor probe. Latvian J. Phys. Techn. Sci., (5), 38-56.

7. Dobulans, R., Cepite, D., Fonavs, E., \& Muzikante, I. (2004). Studies of host-guest thin films of corona-poled betaine-type polar molecules by Kelvin probe technique and atomic force microscopy. Macromol. Symp., 212, 421-426.

8. Mortazavi, M.A., Knoesen, A., Kowel, S.T., Higgins, B.G., \& Dienes, A. (1989). Second-harmonic generation and absorption studies of polymer-dye films oriented by corona-onset poling at elevated temperatures. J. Opt. Soc. Am. B, 6, 733-741.

9. Kim, J-J., Jung, S-D., \& Hwang, W-Y. (1996). Molecular conformation and application of stereoregular PMMA Langmuir-Blodgett films. ETRI Journal 18 (3), 195-206.

10. Muzikante, I., Cepite, D., Fonavs, E., Tokmakov, A., Erts, D., \& Polakov, B. (2003). Incorporated oriented polar molecules in PMMA polymeric films: characterization by Kelvin probe technique and atomic force microscopy. Latv. J. Phys. Tec. Sci., (3), 4955.

11. Meredith, G.R., VanDusen, J.G., \& Williams, D.J. (1982). Optical and nonlinear optical characterization of molecularly doped thermotropic liquid crystalline polymers. Macromolecules, 15, 1385-1389.

\title{
AZOBENZOLU SAVIENOJUMU FOTOIZOMERIZĀCIJAS PROCESI PLĀNĀS KĀRTIN̦ĀS
}

\author{
B. Niparte, I. Muzikante, E. Fonavs, D. Gustiņa \\ Kopsavilkums
}

Molekulāram slēdzim viena no īpašībām ir molekulas spēja pagriezties citā stāvoklī ārējās iedarbības rezultātā, tādējādi izmainot, piemēram, molekulas dipola momenta vērtību. Kā vienas no tādām molekulām ir azobenzolu savienojumi, kuras apstarojot ar noteiktu viļ̣nu garumu, ir novērojama pāreja starp diviem izomēru trans- un cis-stāvokḷiem.

Azobenzola molekulu raksturošanai tiek izmantotas tādas vērtības kā fotoierosinātā virsmas potenciāla vērtības un ātruma izmaiṇas trans/cis fotoizomerizācijā, kā arī optimālā molekulu koncentrācija polimēra matricā. Darbā izpētîtas polimēru plāno kārtiņu ar azobenzola atvasinājumu A-45 fotoierosinātā virsmas potenciāla atkarības no molekulu koncentrācijas, kārtiņu biezuma, kā arī krītošās un absorbētās gaismas intensitātes. Fotoierosinātās virsmas potenciāla izmaiņas ir noteiktas ar Kelvina zondes metodi.

Darbā parādīts, ka fotoierosinātās virsmas potenciāla izmainu amplitūdas vērtības palielinās, palielinot azobenzola molekulu koncentrāciju no 1 līdz 10 wt\%, kā arī palielinot kārtināa absorbētās gaismas intensitāti. Savukārt, fotoierosinātās virsmas potenciāla izmaiņas ātrums ir nemain̄̄gs 